\title{
Mitigating Land Subsidence in the Coachella Valley, California, USA: An Emerging Success Story
}

\author{
Michelle Sneed and Justin T. Brandt \\ California Water Science Centre, U.S. Geological Survey, Sacramento, California, 95819, USA \\ Correspondence: Michelle Sneed (micsneed@usgs.gov)
}

Published: 22 April 2020

\begin{abstract}
Groundwater has been a major source of agricultural, municipal, and domestic water supply since the early 1920s in the Coachella Valley, California, USA. Land subsidence, resulting from aquifer-system compaction and groundwater-level declines, has been a concern of the Coachella Valley Water District (CVWD) since the mid-1990s. As a result, the CVWD has implemented several projects to address groundwater overdraft that fall under three categories - groundwater substitution, conservation, and managed aquifer-recharge (MAR). The implementation of three projects in particular - replacing groundwater extraction with surface water from the Colorado River and recycled water (Mid-Valley Pipeline project), reducing water usage by tiered-rate costs, and increasing groundwater recharge at the Thomas E. Levy Groundwater Replenishment Facility - are potentially linked to markedly improved groundwater levels and subsidence conditions, including in some of the historically most overdrafted areas in the southern Coachella Valley. Groundwater-level and subsidence monitoring have tracked the effect these projects have had on the aquifer system. Prior to about 2010, water levels persistently declined, and some had reached historically low levels by 2010 . Since about 2010 , however, groundwater levels have stabilized or partially recovered, and subsidence has stopped or slowed substantially almost everywhere it previously had been observed; uplift was observed in some areas. Furthermore, results of Interferometric Synthetic Aperture Radar analyses for 1995-2017 indicate that as much as about $0.6 \mathrm{~m}$ of subsidence occurred; nearly all of which occurred prior to 2010. Continued monitoring of water levels and subsidence is necessary to inform the CVWD about future mitigation measures. The water management strategies implemented by the CVWD can inform managers of other overdrafted and subsidence-prone basins as they seek solutions to reduce overdraft and subsidence.
\end{abstract}

\section{Introduction and Background}

Groundwater has been a major source of agricultural, municipal and domestic water supply in the Coachella Valley, California, USA, since the early 1920s (Fig. 1). By about 2010, water levels in many wells in the Coachella Valley had declined by as much as $30 \mathrm{~m}$ and water levels in some wells were at their lowest recorded values (Fig. 1a). Declining water levels can contribute to, or induce, land subsidence in alluvial aquifer systems with compressible fine-grained deposits such as that of the Coachella Valley. Results of Global Positioning System and spirit-leveling surveys were used to determine that as much as $0.15 \mathrm{~m}$ of subsidence occurred in the southern parts of the Coachella Valley during 1930-1996 (Ikehara et al., 1997). Interferometric Synthetic
Aperture Radar (InSAR) analyses were used to determine that as much as $0.6 \mathrm{~m}$ of subsidence occurred during 1995-2010 along the southwestern margins of Coachella Valley in the urban areas of Palm Desert, Indian Wells and La Quinta (Sneed et al., 2014; Fig. 1b). Land subsidence has caused earth fissures and has damaged buildings, roads and water conveyance canals near La Quinta (Clay Stevens, TerraPacific Consultants, Inc., written communication, 2006). Subsidence-induced sags along the Coachella branch of the All-American Canal (Coachella Canal) adversely affected flow, caused loss of freeboard, and caused the water surface to overtop the concrete liner in some areas, which prompted the CVWD to realign a portion of the canal in 2014. Since about 2010, the combination of several water management projects implemented by the CVWD 
have markedly improved groundwater levels in some of the historically most overdrafted areas of the valley. The projects fall under three categories - conservation, managed aquifer-recharge (MAR), and groundwater substitution (using Colorado River and recycled water). The groundwater substitution is used for agriculture, golf-course irrigation, and other non-potable water uses through the Coachella Canal and the Mid-Valley Pipeline (MVP) project (Coachella Valley Water District, 2012; Fig. 1a). Monitoring has tracked the effect that MAR and the reduction in pumpage resulting from these projects have had on groundwater levels (Fig. 1a, b). The marked improvement in groundwater levels that began around 2010 was timely. In 2014, the California legislature passed the Sustainable Groundwater Management Act (SGMA), which stipulates sustainable management of groundwater resources by avoiding certain "undesirable results," including groundwater-level declines and land subsidence. CVWD's groundwater management plans received state approval and meet the requirements of the SGMA (California Department of Water Resources, https://water.ca.gov/Programs/Groundwater20Management/ SGMA-Groundwater-Management/Alternatives, last access: 21 August 2019).

\section{Geographic and Hydrogeologic Setting}

The Coachella Valley is a $1000 \mathrm{~km}^{2}$ northwest-trending valley in arid southeastern California (Fig. 1); the valley receives only about $75 \mathrm{~mm}$ of precipitation annually (California Department of Water Resources, 1964). The northern part of the valley is largely rural but includes the city of Palm Springs. The southern part of the valley has larger urban centers including the cities of Palm Desert, Indian Wells, La Quinta, and Indio, which are interspersed with about 120 golf courses, as well as smaller urban centers such as Coachella and Mecca, where agricultural land use is more prevalent.

The $600 \mathrm{~m}$ thick aquifer system in the Coachella Valley comprises a complex unconsolidated to partly consolidated assemblage of gravel, sand, silt and clay of alluvial and lacustrine origins (California Department of Water Resources, 1979). In the southern Coachella Valley, the aquifer system consists of a semiperched aquifer zone, an upper aquifer, a confining layer (lacustrine deposits), and a lower aquifer. The lower aquifer is the most productive source of groundwater in the southern Coachella Valley. In the northern Coachella Valley, the confining layer is absent such that the aquifer system is not subdivided. Sediments tend to be finer grained (contain more silt and clay) in the southern part of the valley compared to the northern part because of the greater distance from the sediment source areas in the north and because of lacustrine deposition in the ancient Lake Cahuilla (California Department of Water Resources, 1964, 1979). Furthermore, lithologic analyses indicated that fine-grained compressible sediments were preferentially deposited in the southwestern margin of the valley, resulting in interbedded aquitards with variable thicknesses (Sneed et al., 2014).

The general direction of groundwater flow is southeastward toward the Salton Sea. Northwest trending faults generally are parallel to the flow direction but affect the movement of groundwater in some parts of the valley (California Department of Water Resources, 1964). InSAR analysis indicated that the northern and eastern extents of subsidence in Palm Desert, Indian Wells, and La Quinta terminate abruptly, and are coincident with an inferred fault (Jennings, 1977; Sneed et al., 2014; Fig. 1). Abrupt areal changes in subsidence can be the result of faults separating compressible from less-compressible deposits or acting as barriers to groundwater flow (Galloway et al., 1999). Hydrostratigraphic analyses led Sneed et al. (2014) to conclude that differences in the sediment compressibilities across the inferred fault are probable.

\section{Groundwater Levels and Land Subsidence}

Groundwater pumping between the early 1920s and the late 1940s resulted in seasonal groundwater-level fluctuations superimposed on declines of as much as $15 \mathrm{~m}$. In 1949, the importation of Colorado River water through the Coachella Canal to the southern Coachella Valley began. The importation of surface water resulted in decreased groundwater pumping during the 1950s through the 1970s, and groundwater levels in some wells consequently recovered by as much as $15 \mathrm{~m}$. Starting in the late 1970s, however, the demand for water increased to the point that groundwater levels again declined in response to increased pumping. By about 2010, water levels in many wells in the southern Coachella Valley had declined by as much as $30 \mathrm{~m}$, with some reaching historically low levels (Fig. 1a, b).

Land subsidence in the southern part of the Coachella Valley has been monitored since 1995 using InSAR methods. As much as $0.6 \mathrm{~m}$ of subsidence had occurred by 2010 , with the local maxima in the urbanized areas along the southwestern margin of the valley (Sneed et al., 2014; Fig. 1b). Analysis indicated subsidence rates as high as about $50 \mathrm{~mm} \mathrm{yr}^{-1}$ in some areas over the 15 year period - including during periods of seasonal water-level recovery. Subsidence occurring during periods of water-level recovery indicates that residual compaction of thick clay aquitards occurred and could be a substantial component of total compaction in these areas (Sneed et al., 2014). Land subsidence in the northern part of the valley prior to 2010 had not been monitored as closely as in the southern part, but InSAR analyses indicated landsurface stability during 2003-2005 (Martin et al., 2011).

Since about 2010, groundwater and land subsidence conditions - including in some of the historically most overdrafted areas in the southern part of the valley - have markedly improved. Groundwater-level recovery during 2010-2017 coincided with substantially reduced subsidence rates or up- 

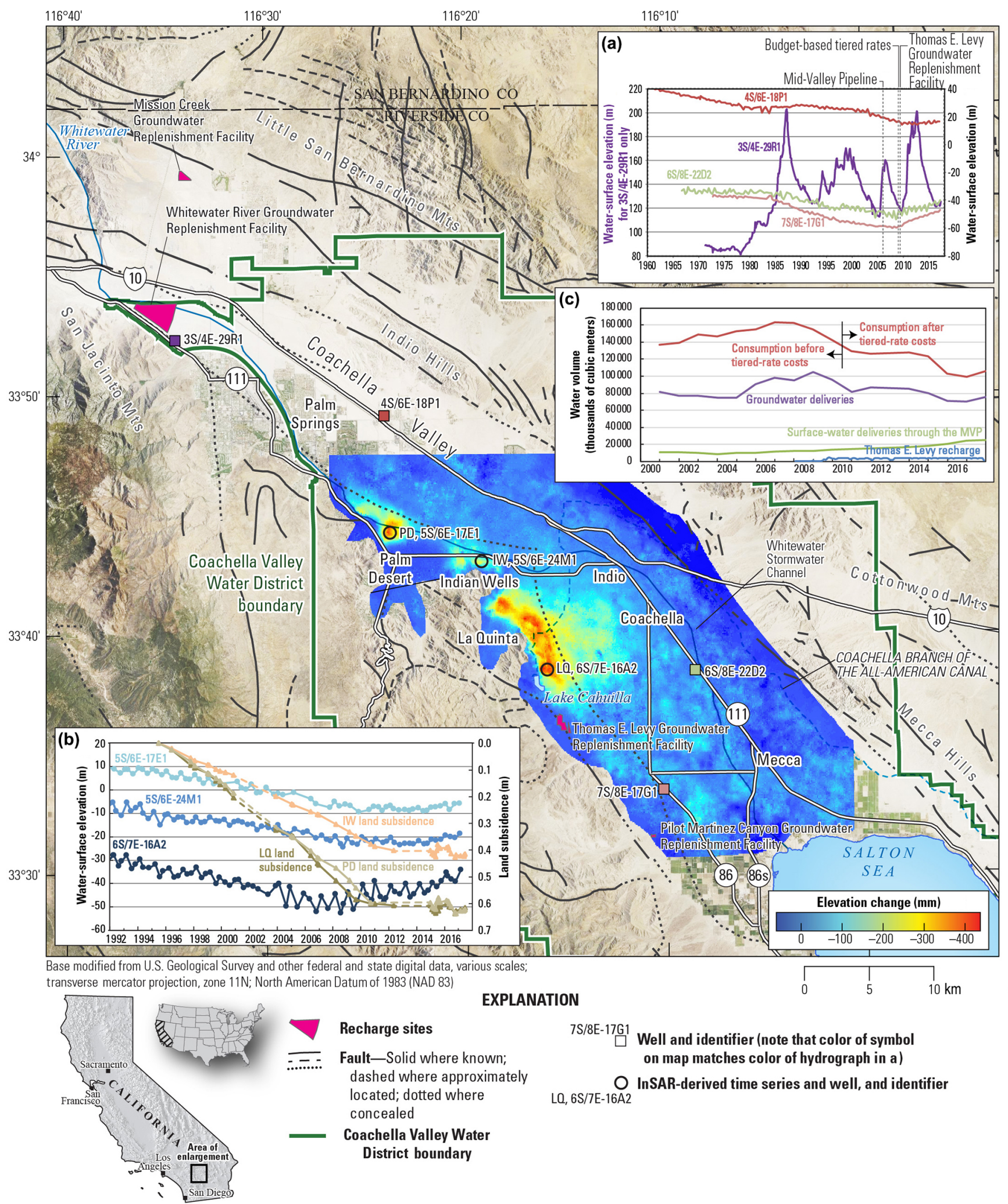

Recharge sites

Fault-Solid where known; dashed where approximately loc ated; dotted where concealed

Coachella Valley Water District boundary

Figure 1. The Coachella Valley, California, USA with an interferogram showing land-surface deformation for 1995-2017 (excludes 8 November 2000-30 November 2003 and 19 September 2010-28 December 2014); (a) Groundwater levels in selected wells and mitigation strategies, 1960-2017; (b) InSAR-derived deformation at selected locations (dashed where estimated), and groundwater levels in selected wells, 1992-2017; (c) Water volumes for groundwater deliveries, surface-water deliveries through the Mid-Valley Pipeline, recharge at the Thomas E. Levy Groundwater Replenishment Facility, and consumption according to the implementation of tiered-rate costs, $2000-2017$. 
lift compared to subsidence rates during 1995-2010, when groundwater levels declined (Fig. 1b). Subsidence rates during 2010-2017 were generally less than half the rates computed for 1995-2010, and in most cases the rates were reduced by $75 \%$. Furthermore, the subsidence rates generally slowed throughout 2010-2017. The northern part of the valley uplifted by as much as $60 \mathrm{~mm}$ during 2014-2017.

The trend reversal in the southern part of the valley provides new insights into aquifer-system mechanics. While many areas had stopped subsiding or had uplifted during 2010-2017 during water-level recovery, the few areas that did subside during water-level recovery indicate a mixed aquifer-system response. It is likely that the coarser-grained aquifers and thin, quickly equilibrating aquitards expanded elastically, while the thicker, slowly draining aquitards compacted (residual compaction). This mixed, mechanical response of the aquifer system indicates that the stresses causing compaction of the thicker aquitards are not represented by the measured stresses (water levels in aquifers). Because of the impedance of groundwater flow in the aquitards, changes in hydraulic head in the aquifers may not have yet occurred throughout a significant part of the thicker aquitards. If this is the case, subsidence rates are expected to slow asymptotically if groundwater levels continue to recover or stabilize.

\section{Mitigation of Groundwater Overdraft and Land Subsidence}

The stabilization and recovery of groundwater levels, and the reduced rates or cessation of subsidence, correspond to the timing of various conservation, MAR, and groundwater substitution projects implemented by the CVWD to increase recharge or reduce reliance on groundwater (Fig. 1c). Projects have been implemented by the CVWD since 1973 throughout the valley to address overdraft, but the implementation of three projects in particular are potentially linked to markedly improved groundwater levels since about 2010 in some of the historically most overdrafted areas of the valley. These projects are groundwater substitution through the MVP project since 2006, budget-based tiered-rate costs since 2009, and MAR at the Thomas E. Levy Groundwater Replenishment Facility since 2009. Additionally, drought-induced conservation requirements mandated by the State of California beginning in 2014 likely contributed to the improved conditions.

The multi-pronged water-resource management approach includes agricultural and urban (recreational, residential, and commercial) water users. In the mostly rural northern parts of the Valley, the fluctuations in groundwater levels are partly driven by recharge operations at the Whitewater and Mission Creek Groundwater Replenishment Facilities, which began in 1973 and 2002, respectively (Fig. 1, for example, well 3S/4E-29R1 in Fig. 1a; Coachella Val- ley Water District, 2012). These groundwater replenishment facilities are in the northwest part of the valley, such that the recharged water flows southeasterly towards agricultural and urban centers. Further south, near Palm Desert, Indian Wells, and La Quinta, where the highest subsidence rates were measured between 1995 and 2010, groundwater-level responses to those recharge operations diminish and seasonal and longer-term trends in groundwater-levels and landsurface deformation become more prevalent (Fig. 1a, b). This largely urbanized area is where many of the conservation projects were expected to be more commonly adopted. The conservation projects include turf conversion to less waterintensive landscape (including golf courses), residential and large landscape smart water controllers, and smart water nozzles, among other conservation projects. The implementation of budget-based tiered-rate costs in 2009 most closely coincides with the reversal of long-term groundwater-level declines in the area (Fig. 1a, b). In addition, more than a dozen new connections from golf courses, resorts, and other businesses to the MVP project since 2006 have contributed to reduced groundwater use (Fig. 1c).

In the largely rural and agricultural areas south of La Quinta, the effects of recharge operations at the Thomas E. Levy Groundwater Replenishment Facility, which began in 2009, are superimposed on the seasonal and longer-term trends in both groundwater levels and land-surface deformation (Fig. 1a-c). These recharge operations coincide with the abrupt reversal of long-term groundwater-level declines in the area. Additionally, the flood-to-drip agricultural rebate conservation project implemented by CVWD starting in 2016 was expected to be more commonly adopted in this area but has since been discontinued.

\section{Summary}

Groundwater has been a major source of agricultural, municipal and domestic water supply in the Coachella Valley, resulting in water-level declines of as much as $30 \mathrm{~m}$ by about 2010, when many reached historically low levels (Sneed et al., 2014). These declines resulted in as much as $0.15 \mathrm{~m}$ of subsidence by 1996 in the southern part of the valley, and as much as $0.6 \mathrm{~m}$ of subsidence between 1995 and 2010 along the southwestern margin of the valley, where differential subsidence has damaged buildings, roads, water conveyance canals, and other infrastructure. Starting in about 2010, the combination of several projects implemented by the CVWD to increase recharge or reduce reliance on groundwater coincided with wide-spread stabilization and recovery of groundwater levels and a substantial slowing or cessation of subsidence in some of the historically most overdrafted areas. Phase 1 of the Palm Desert Groundwater Replenishment Facility, which consists of recharge ponds adjacent the Whitewater Stormwater Channel in Palm Desert, began recharge operations in January 2019, with the management goal of 
mitigating the continued, albeit slowed, groundwater-level declines and associated subsidence in the Palm Desert and Indian Wells areas. Phase II of the Palm Desert Groundwater Replenishment Facility involves construction of additional recharge ponds in the Whitewater Stormwater Channel in Palm Desert. As the CVWD continues to implement such projects, future monitoring could track the resulting effects on the aquifer system and help inform future mitigation measures, as the CVWD has done using the results of previous studies. The water management strategies implemented by the CVWD can inform managers of other overdrafted and subsidence-prone basins as they seek solutions to comply with the SGMA.

Data availability. The InSAR data presented in this report are available at https://www.sciencebase.gov/catalog/item/ 5cfea3cfe4b0156ea564502c (last access: 10 March 2020, Sneed, 2020). The water-surface elevation and water volume data were provided by the Coachella Valley Water District.

Author contributions. MS designed and directed the study. JB processed the data. MS and JB analyzed the data and wrote the paper.

Competing interests. The authors declare that they have no conflict of interest.

Special issue statement. This article is part of the special issue "TISOLS: the Tenth International Symposium On Land Subsidence - living with subsidence". It is a result of the Tenth International Symposium on Land Subsidence, Delft, the Netherlands, 17-21 May 2021.

\section{References}

California Department of Water Resources: Coachella Valley investigation: California Department of Water Resources, Bulletin 108, 145 pp., 1964.

California Department of Water Resources: Coachella Valley area well standards investigation: Los Angeles, California Department of Water Resources, Southern District, 40 pp., 1979.

Coachella Valley Water District: Coachella Valley Water Management Plan 2010 Update, available at: http://www.cvwd.org/DocumentCenter/View/1321/

Coachella-Valley-Water-Management-Plan-Final-Report-PDF? bidId (last access: 21 August 2019), Final Report, 286 pp., 2012.

Galloway, D. L., Jones, D. R., and Ingebritsen, S. E: Land subsidence in the United States, U.S. Geological Survey Circular 1182, 175 pp., 1999.

Ikehara, M. E., Predmore, S. K., and Swope, D. J.: Geodetic network to evaluate historical elevation changes and to monitor land subsidence in Lower Coachella Valley, California, 1996, U.S. Geological Survey Water-Resources Investigations Report 974237, scale $1: 63000,1$ sheet (folded in envelope), 1997.

Jennings, C. W.: Geologic Map of California, California Division of Mines and Geology, Geologic Data Map No. 2, scale 1 : 750 000, 1977.

Martin, P. (Ed.): with contributions by Brandt, J., Catchings, R. D., Christensen, A. H., Flint, A. L., Gandhok, G., Goldman, M. R., Halford, K. J., Langenheim, V. E., Martin, P., Rymer, M. J., Schroeder, R. A., Smith, G. A., and Sneed, M.: The source, discharge, and chemical characteristics of water from Agua Caliente Spring, Palm Springs, California: U.S. Geological Survey Scientific Investigations Report 2011-5156, 106 pp., 2011.

Sneed, M.: Global Positioning System Survey data for 2015, and Interferometric Synthetic Aperture Radar Data for 1995-2017, Coachella Valley, Riverside County, California: U.S. Geological Survey data release, available at: https://www.sciencebase. gov/catalog/item/5cfea3cfe4b0156ea564502c, last access: 10 March 2020.

Sneed, M., Brandt, J. T., and Solt, M.: Land subsidence, groundwater levels, and geology in the Coachella Valley, California, 19932010, U.S. Geological Survey Scientific Investigations Report 2014-5075, https://doi.org/10.3133/sir20145075, 62 pp., 2014. 